doi: 10.32620/oikit.2021.93.07

УДК 629.7.01

О. Г. Гребеніков, А. С Калоша

\title{
Аналіз сучасного стану розвитку безпілотних літальних мікроапаратів мультикоптерного типу
}

\author{
Національний аерокосмічний університет ім. М. Є. Жуковського \\ "Харківський авіаційний інститут»
}

\begin{abstract}
Розроблення безпілотних літальних апаратів становить великий інтерес як для найбільших авіабудівних компаній, так і ентузіастів-проектувальників, і серед загального обсягу розробок обсяг мультикоптерних безпілотних апаратів займає одну з лідируючих позицій. У зв'язку з цим актуальним $€$ аналіз існуючих напрацювань та визначення майбутніх досліджень у цьому напрямку. Мультикоптерні безпілотні апарати мають широкий діапазон функцій як в сфері військового, так і цивільного використання.

У роботі зібрано та проаналізовано статистичні дані мікробезпілотних літальних апаратів мультикоптерного типу для визначення досягнень у сфері проектування мікробезпілотних літальних апаратів (БПЛА). Розглянуто діючу класифрікацію БПЛА, в результаті аналізу статистичних даних було запропоноване ії̈ розширення. Описано злітно-масові характеристики мікроБПЛА. Наведені таблиці, що показують існуючі БПЛА. Крім того, визначені льотно-технічні характеристики, аеродинамічні схеми і тип двигуна, які найбільш раціонально підходять для мікробезпілотних літальних апаратів відповідно до їх призначення і класу.

На основі отриманих даних було побудовано модель-прототип мікроБПЛА з покращеними характеристиками. Модель успішно виконала всі поставлені задачі. Це вказує на те, що новий БПЛА «Страх-1» $є$ успішним проектом і він має можливість дистанційного керування за допомогою телефону або будь-якої іншої апаратури, призначеної для цього. Крім того, проектований апарат може додатково зависати у заданих координатах.

«Страх-1» впевнено виконує поставлені задачі в автоматичному режимі, а також самостійно приймає рішення про повернення в початкову точку зльоту, якщо: відбулася втрата зв'язку, рівень заряду акумуляторної батареї досягнув певного рівня, БПЛА завершив своє завдання чи було використано більше міліампер, ніж задано вихідними параметрами. Дрон має можливість летіти в режимі «Follow me» за обраним GPS передавачем. Квадрокоптер тестували при складних погодних умовах, коли сила вітру досягала 8 балів (близько $22 \mathrm{~m} / \mathrm{c}$ ). Також були проведені тестування на завадостійкість в діапазоні промислових частот (від 2.4 Ггц до 5.8 Ггц.).
\end{abstract}

Ключові слова: мікроБПЛА мультикоптерного типу; льотно-технічні характеристики; тривалість польоту; двигун; компонування; дрон.

У наш час розвиток безпілотних апаратів переживає величезний стрибок, що викликано бажанням людства автоматизувати своє повсякденне життя і зробити можливим виконання операцій, недоступних людині. Важливими складовими рентабельності проектування БПЛА такого типу і основними причинами їх розвитку $є$ обсяг фрінансування науково-дослідної роботи в цьому напрямку в державних установах і приватних організаціях, що вказує на інтерес до теми.

До додаткових питань, які безумовно виникнуть на початку можливої роботи над створенням мікроБПЛА, слід віднести здатність розроблення і виробництва апаратів подібного типу в Україні.

За наявності в Україні наукових, виробничих і випробувальних організацій, які можуть розробляти і виготовляти БПЛА (Харківське державне авіаційне виробниче підприємство "ХДАВП", Державне підприємство Міністерства оборони України "Чугуївський авіаремонтний завод", НДІ проблем фрізичного моделювання "XАІ", КБ "Авіа", ВАТ "МоторСіч", ДП ЗМБК "Івченко-Прогрес"), а також 
платформи для створення повного замкнутого циклу розроблення і виробництва, $є$ можливим створення БПЛА такого класу. Таким чином, можна прийти до висновку, що розроблення і створення мікроБПЛА $є$ не тільки можливим, але і затребуваним напрямком. Наступним кроком має стати визначення підтипів таких БПЛА і виділення досягнень, отриманих в цій області для здійснення подальших цілей проектування.

Міжнародною асоціацією з безпілотних систем було запропоновано універсальну класифікацію БПЛА, яка об'єднує багато критерії в (табл.1) наведено цю класифікацію з англомовними еквівалентами категорій і абревіатур.[5]

Таблиця 1

Універсальна класифікація БПЛА щодо льотних параметрів

\begin{tabular}{|c|c|c|c|c|c|c|}
\hline \multirow{2}{*}{ Група } & \multicolumn{2}{|c|}{ Категорія } & \multirow{2}{*}{$\begin{array}{c}\text { 3літна } \\
\text { маса, кг }\end{array}$} & \multirow{2}{*}{$\begin{array}{c}\text { Дальність } \\
\text { польоту, км }\end{array}$} & \multirow{2}{*}{$\begin{array}{c}\text { Висота } \\
\text { польоту, } \\
\text { м }\end{array}$} & \multirow{2}{*}{$\begin{array}{c}\text { Тривалість } \\
\text { польоту, } \\
\text { год }\end{array}$} \\
\hline & укр. & англ. & & & & \\
\hline \multirow{3}{*}{$\begin{array}{l}\text { Малі } \\
\text { БПЛА }\end{array}$} & НаноБПЛА & Nano & $0 \ldots 0,025$ & $0 \ldots 1$ & 100 & 1 \\
\hline & МікроБПЛА & Micro & $0.025 \ldots 5$ & $1 \ldots 10$ & 250 & 1 \\
\hline & МініБПЛА & Mini & $5 \ldots 150$ & $1 \ldots 10$ & $150 \ldots 300$ & $1 \ldots 2$ \\
\hline \multirow{5}{*}{$\begin{array}{c}\text { Тактичні } \\
\text { БПЛА }\end{array}$} & $\begin{array}{c}\text { Легкі БПЛА для } \\
\text { контролю } \\
\text { переднього } \\
\text { краю оборони }\end{array}$ & $\begin{array}{c}\text { Close Range } \\
\text { (CR) }\end{array}$ & $25 \ldots 150$ & $10 \ldots 30$ & 3000 & $2 \ldots 4$ \\
\hline & $\begin{array}{c}\text { Легкі БПЛА з } \\
\text { малою дальніс- } \\
\text { тю польоту }\end{array}$ & $\begin{array}{c}\text { Short Range } \\
(\mathrm{SR})\end{array}$ & $50 \ldots 250$ & $30 \ldots 70$ & 3000 & $3 \ldots 6$ \\
\hline & Середні БПЛА & $\begin{array}{c}\text { Medium } \\
\text { Range (MR) }\end{array}$ & $150 \ldots 500$ & $70 \ldots 200$ & 5000 & $6 \ldots 10$ \\
\hline & $\begin{array}{c}\text { Середні БПЛА } \\
\text { з великою } \\
\text { тривалістю } \\
\text { польоту } \\
\end{array}$ & $\begin{array}{c}\text { Medium } \\
\text { Range } \\
\text { Endurance } \\
\text { (MRE) }\end{array}$ & $\begin{array}{c}500 \ldots \\
1500\end{array}$ & $>500$ & 8000 & $10 \ldots 18$ \\
\hline & $\begin{array}{c}\text { Маловисотні } \\
\text { БПЛА для } \\
\text { проникнення } \\
\text { вглиб оборони } \\
\text { супротивника }\end{array}$ & $\begin{array}{l}\text { Low Altitude } \\
\text { Deep } \\
\text { Penetration } \\
\text { (LADP) }\end{array}$ & $\begin{array}{l}250 \ldots \\
2500\end{array}$ & $>250$ & $50 \ldots 9000$ & $0,5 \ldots 1$ \\
\hline
\end{tabular}

При цьому розрізняють БПЛА за призначенням, (на наукові і прикладні), які, в свою чергу, додатково поділяють на військові і цивільні (рис. 1).

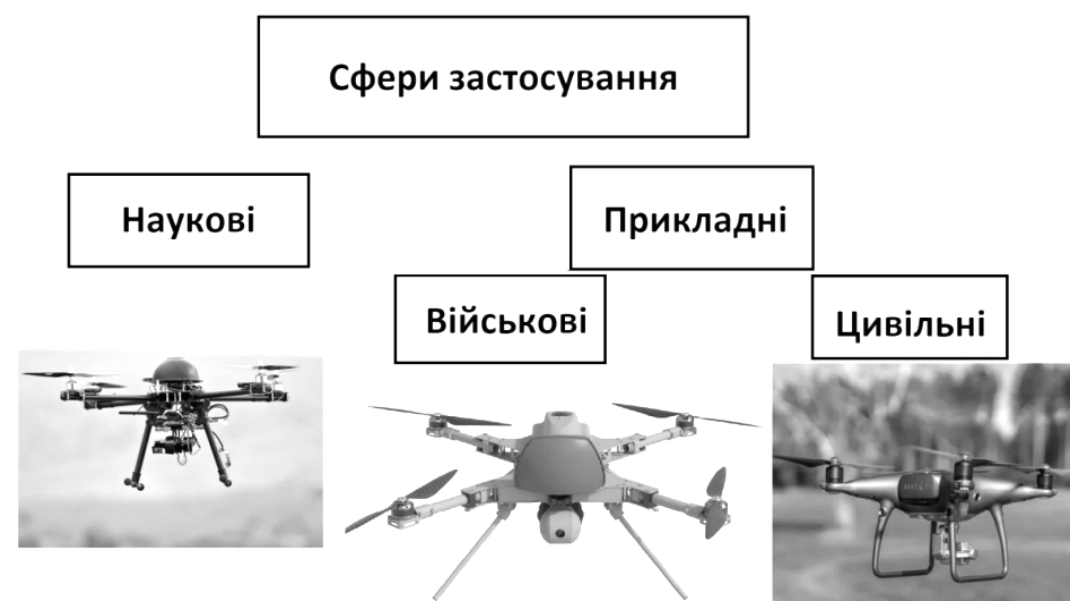

Рис. 1. Сфрери застосування БПЛА

Науковий і цивільний сектори мікроБПЛА становлять невелику частку, 
порівняно з військовим, оскільки застосування стратегічних БПЛА історично почалося раніше, а використання цивільних апаратів $€$ не таким вже тривалим. Незважаючи на це, область застосування такого класу безпілотних літальних апаратів у повсякденному житті є досить широкою

Розглянемо можливі способи застосування цивільних і військових БПЛА.

Наука. Сучасні наукові дослідження важко уявити без застосування комплексів БПЛА. Вони дозволяють спостерігати і контролювати багато процесів, стежити за змінами, особливо якщо вони стосуються природного або індустріального об'єкта.

Безпека. Особливості експлуатації дозволяють використовувати такі БПЛА для охорони таких об'єктів: державних кордонів, людей, стратегічно важливих будівель і конструкцій, а також під час військових операцій для виявлення людей, об'єктів.

Надзвичайні ситуації. У міністерстві надзвичайних ситуацій давно використовують комплекси для проведення таких дій: пошуку людей (які загубилися і постраждали), оповіщення населення, виконання рятувальних операцій, виявлення лісових пожеж, повеней.

Головне завдання, яке виконує БПЛА це спостереження. за такими об'єктами: електростанціями, АЕС, будовами сільського господарства, угіддями, полями, ЛЕП і електромережами, земельними, водними, лісовими ресурсами, нафто- і газопроводами.

У цей час безпілотні літальні апарати різних типів і призначення не тільки стоять на озброєнні багатьох армій світу, а й активно використовуються в цивільній авіації. Широкий спектр їх практичного застосування охоплює вирішення таких основних завдань:

- оптична, радіолокаційна, хімічна, бактеріологічна та радіаційна розвідка;

- нанесення ударів для знищення об'єктів і живої сили супротивника;

- радіоелектронна боротьба;

- моніторинг екологічної обстановки;

- підтримання мережної телекомунікації;

- контроль морського судноплавства;

- спостереження за проведенням масових заходів;

- контроль і моніторинг газових і нафтових магістралей;

- телевізійні трансляції та кінозйомка.

До основних цивільних завдань мікроБПЛА належить їх застосування як супутників, які можна використовувати для таких цілей:

- (тропосферні)аналізу клімату, радіаційного фону і т.п.

- передачі радіосигналів;

- фотозйомки місцевості;

- виявлення лісових пожеж та допомоги в їх гасінні;

- спостереження за кордонами держави;

- виявлення злочинної діяльності різного роду;

- виявлення покладів природних ресурсів і копалин;

- спостереження за будівництвом надвеликих об'єктів;

- спостереження за аграрною діяльністю;

- виявлення, попередження стихійних лих і ліквідації їх наслідків.

Мета застосування мікроБПЛА у військовій сфері полягає, зазвичай у використанні їх як розвідувальних комплексів. Однак також їх застосовують для таких цілей: 
- зв'язку з наземними, морськими і повітряними бойовими групами, їх віддаленого управління;

- збирання інформації;

- доставки безпілотних дронів-мішеней на місце їх застосування.

За результатами збирання та оброблення статистичних даних мікроБПЛА була складена зведена табл.2, в якій вказано назву, країну, рік вводу в експлуатацію, узагальнене призначення БПЛА, злітну масу, дальність і тривалість польоту, статичну висоту, розміри, схему.

Таблиця 2

Статистичні дані щодо БПЛА

\begin{tabular}{|c|c|c|c|c|c|c|c|c|c|}
\hline Назва & Країна & Категорія & Схема & $\begin{array}{c}\text { Розміри, } \\
\text { см }\end{array}$ & $\begin{array}{c}\text { Маса, } \\
\text { кг }\end{array}$ & $\begin{array}{c}\text { Дальність } \\
\text { польоту, } \\
\text { км }\end{array}$ & $\begin{array}{c}\text { Висота } \\
\text { польоту, } \\
\text { м }\end{array}$ & $\begin{array}{c}\text { Тривалість } \\
\text { польоту, } \\
\text { хв }\end{array}$ & Рік. \\
\hline «Волк-18» & Росія & Військовий & Квадро & $60 \times 60 \times 18$ & 4.9 & 15 & 2000 & 30 & 2021 \\
\hline Kargu-2 & Турція & Військовий & Квадро & $60 \times 60 X 43$ & 7 & $5-10$ & 2800 & 30 & 2020 \\
\hline «РС-1» & Україна & Військовий & Квадро & $53 \times 48 X 13$ & 3.6 & 5 & 500 & 38 & 2020 \\
\hline «Берегиня» & Україна & Військовий & Квадро & $40 \times 40 \times 30$ & 2 & 10 & 1500 & 25 & 2019 \\
\hline DragonFly & Польша & Військовий & Квадро & $50 \times 50 \times 32$ & 5 & 10 & 200 & 20 & 2016 \\
\hline
\end{tabular}

Розглянемо існуючі квадрокоптери (Рис. 2).

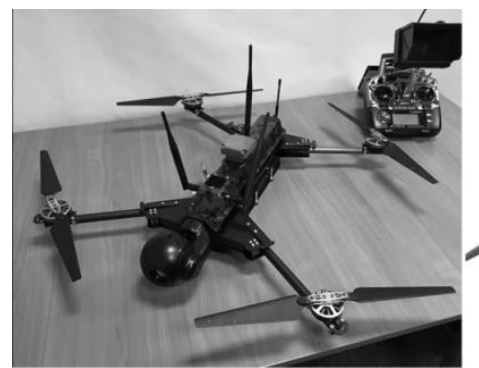

1

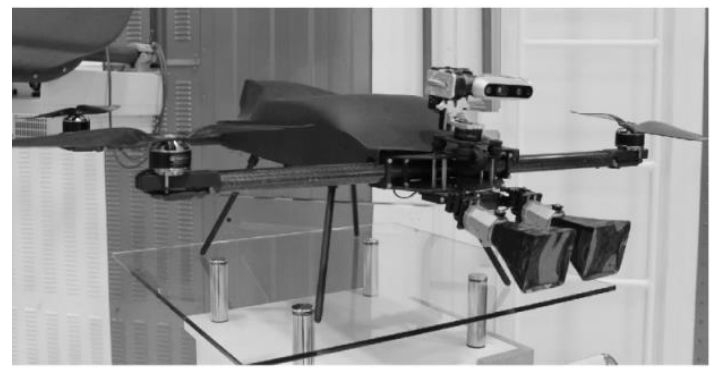

4

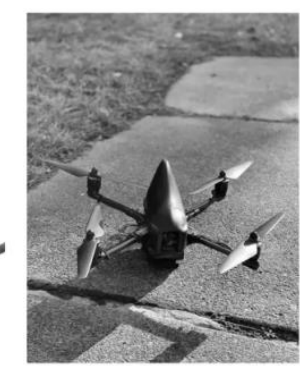

2

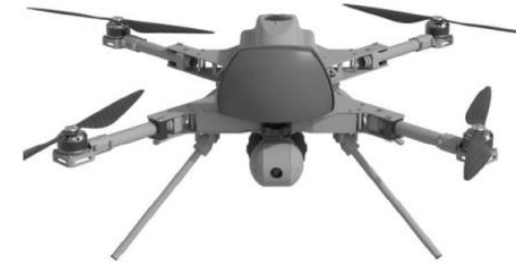

3

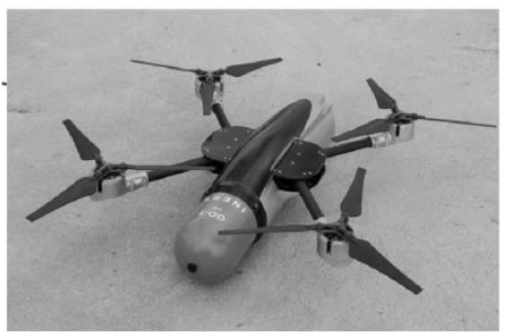

5

Рис. 2. Загальний вигляд: 1 - «РС-1», 2 - «Берегиня», 3 - Kargu-2; 4 - «Волк-18»; 5 - DragonFly

Далі розглянемо застосовність аеродинамічних схем у компонуванні мікромультикоптерного типу БПЛА, (Рис. 3).

Найбільшого поширення набула нормальна квадрокоптерна схема, 3 огляду на її переваги: чотири двигуни знаходяться в чистому незбуреному потоці і не затінюються; менша маса конструкції; найкращі балансування і керованість порівняно зі схемами трикоптера. До недоліків можна віднести: в разі пош- 
кодження одного із двигунів - квадрокоптер не зможе летіти на відміну від співвісного октокоптера чи гексакоптера. Незважаючи на недоліки, що стосуються «живучості» такого типу БПЛА, він буде суттєво дешевшим, надійнішим, компактнішим, легшим.

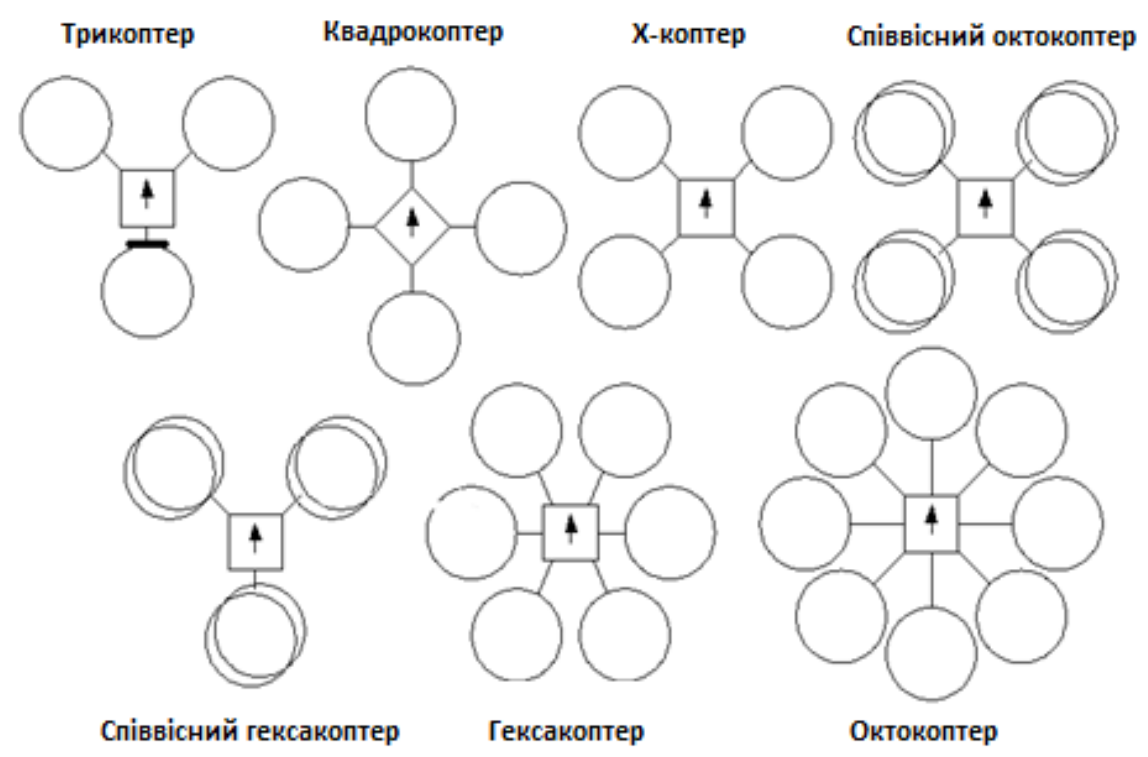

Рис.3. Мультироторні схеми

Вибір двигуна визначається такими характеристиками, як злітна маса, тривалість і швидкість польоту, а також максимальна висота польоту. Кількість двигунів вибирають з умов живучості та безпеки польотів.

Для розвідників (з тривалістю польоту менше години) визначено необхідне застосування електродвигуна з живленням від Li-Pol-батареї, оскільки така силова установка має меншу масу.

Оскільки область завдань мікроБПЛА досить широка, то не дивно, що значення злітної маси таких апаратів лежать в широкому діапазоні. Так, в діапазоні мас от 0.25...5кг домінують БПЛА з електродвигунами, які виконують розвідувальні і наглядові функції і не мають ніякого корисного навантаження.

Більшість літальних апаратів має корисне навантаження: маса вантажів БПЛА, а також маса цільової апаратури. Зі збільшенням маси стерпного вантажу зростає злітна маса БПЛА. Ефективність мікроБПЛА в деякій мірі визначає коефріцієнт корисної віддачі БПЛА:

$$
K_{\text {вid }}=\frac{m_{\kappa . H .}}{m_{0}} ;
$$

де $K_{\text {від }}$ - коефріцієнт віддачі;

$m_{\kappa . н . ~}$ - маса корисного навантаження;

$m_{0}$ - злітна маса першого наближення.

Швидкість польоту безпосередньо впливає на мобільність і тривалість польоту безпілотного апарата, що вкрай важливо для апаратів наглядовою i розвідувального призначення.

Апарати з найбільшою тривалістю польоту (понад одну годину) оснащені електродвигунами і мають малу швидкість польоту (до 50 км/год.). У діапазоні 
витривалості в $30 \ldots 60$ хвилин.

Для виконання і визначення сфери наукових завдань важливою характеристикою є висота польоту.

Оскільки основним завданням, яке ставиться перед мікроБПЛА, є розвідка і спостереження, то площа зони покриття РЛС БПЛА стає важливою характеристикою.

Отже, при однакових системах спостереження найбільш ефективним 3 точки зору виконання завдань розвідки є БПЛА з більшою можливою висотою польоту. Таким чином, збільшення максимальної висоти польоту при найменшій масі дозволить отримати ефективний БПЛА з великою тривалістю польоту,[6].

Тепер розглянемо основні компоненти квадрокоптера.

Двигуни. Основним показником безколекторного мотора $є$ кількість оборотів за хвилину на одиницю напруги (В). Найбільшою популярністю користуються двигуни з кількістю обертів від 300 до 1100. Двигуни,з кількістю обертів близько 1 000, варто встановлювати на невеликі моделі масою до 3 кг.

При виборі такого компонента треба враховувати, що кожен двигун є розрахованим під певні напругу і максимальний струм.

Регулятор. Контролює роботу двигунів. Завдання регулятора полягає в тому, щоб передати енергію постійного струму акумулятора трифазному двигуну. При виборі даного компонента слід варто враховувати особливості двигунів. Якщо вони розраховані на струм до 30 А, то і регулятор необхідно підбирати 3 подібними характеристиками, щоб уникнути перегріву.

Акумулятор. Оптимальним варіантом для мікроквадрокоптера масою 2...2.5 кг 450 класу буде акумулятор Li-Pol 4 S з ємністю 8000 мАг що забезпечить до 25 хвилин польоту.

Польотний контролер. Відповідає за швидкість обертання гвинтів та інші завдання. У загальному розумінні таких пристрій виконує зчитування показань різних датчиків і каналів управління, оброблення отриманої інформації і видачу керуючих сигналів двигунів. Польотний контролер використовує різні датчики, але в обов'язковому порядку, має бути, трьохосьовий гіроскоп і акселерометр для вимірювання кутової швидкості і прискорення а також датчики GPS, OSD, Telemetry 915 ГГц, Reciver 2,4 ГГц, UBEC, FPV 5,8 ГГц

Апаратура керування. Щоб успішно керувати мікроБПЛА, необхідна апаратура з мінімальною кількістю каналів $6 \mathrm{CH}$. Це потрібно, щоб керувати параметрами газу, крену, тангажу, рискання та режиму.

Для виконання цього проекту були вибрані такі комплектуючі:

1. Регулятор Simonk 30 A 2-4 S;

2. Двигуни DJI 2212 - 920 kv;

3. Польотний контролер АРМ 2.8;

4. Гвинти DJI 9450cw / 9450;

5. GPS Radiolink;

6. OSD APM;

7. Telemetry 3DR $915 \mathrm{Ghz}$;

8. Receiver 2.4Ghz FlySky IA6B;

9. UBEC $5 \mathrm{v} / 5 \mathrm{~A}$;

10. FPV 5.8Ghz $600 \mathrm{mw}$;

11. GoPro hero 3 black+;

12. Radiomaster TX16s;

13. TBS Discovery; 
14. Eachine EV800D;

15. Multistar 4s $8000 \mathrm{mAh}$;

16. Imax b6 original $50 \mathrm{~W}$.

3 цих компонентів було зібрано комплексний мікроБПЛА «Страх-1».

На рис. 4 зображені внутрішні компоненти.

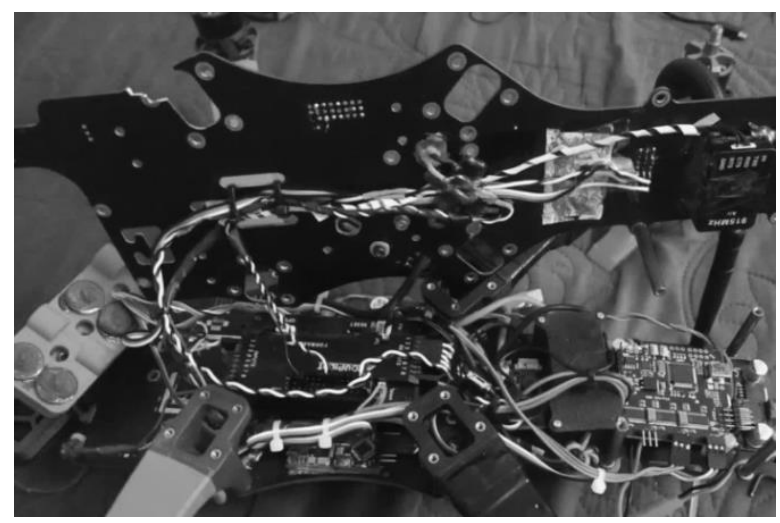

Рис.4. Комплексний мікро БПЛА «Страх-1»

На рис. 5 показано загальний вигляд комплексного мікроБПЛА, а на рис. 6 - його випробування.

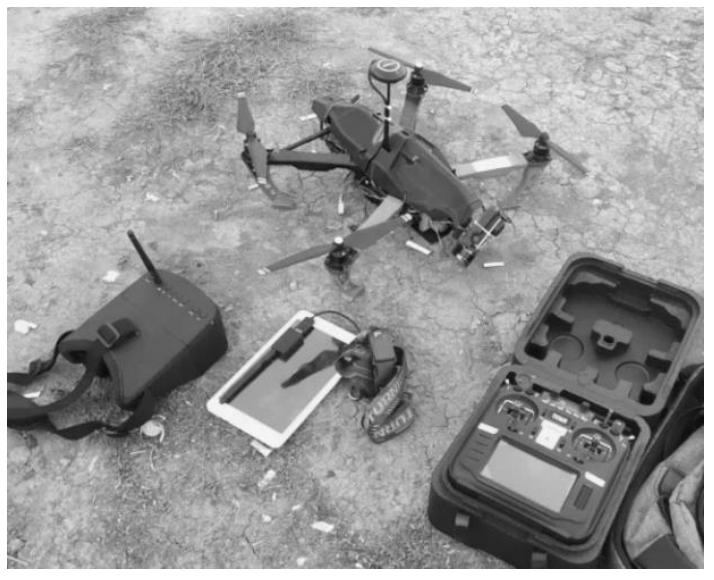

Рис.5. Загальний вигляд комплексного мікроБПЛА
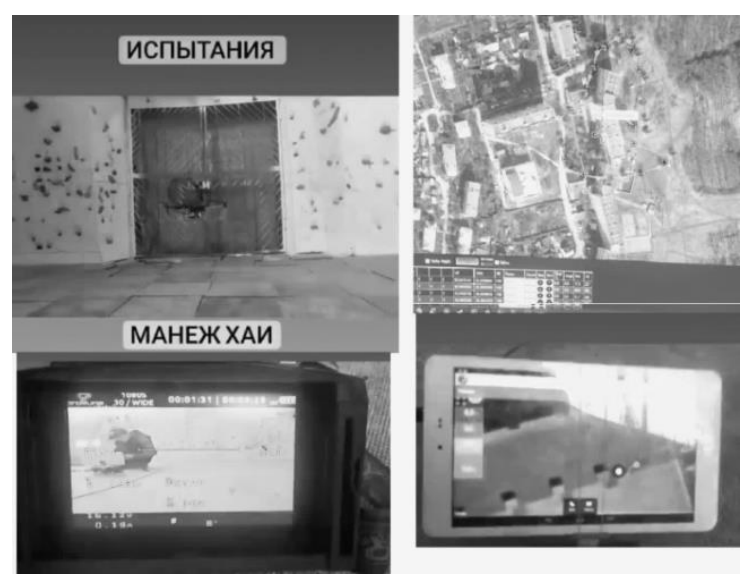

Рис. 6. Випробування мікроБПЛА в манежі «XAl» 
Підводячи підсумки, можна відзначити, що новий мікроБПЛА «Страх-1», розроблений в «XAl», має характеристики наведені в табл. 3

Таблиця 3

Характеристики проектованого мікроБПЛА «Страх-1»

\begin{tabular}{|c|c|c|c|c|}
\hline Назва & Країна & Категорія & Схема & Розміри, см \\
\hline «Страх-1» & Україна & Цивільний & Квадро & $68 \times 55 \times 27$ \\
\hline Маса, кг & $\begin{array}{c}\text { Дальність } \\
\text { польоту, км }\end{array}$ & $\begin{array}{c}\text { Висота } \\
\text { польоту, м }\end{array}$ & $\begin{array}{c}\text { Тривалість } \\
\text { польоту, хв }\end{array}$ & Рік. \\
\hline 2,5 & 15 & 2000 & 25 & 2021 \\
\hline
\end{tabular}

\section{Висновки}

Проведено аналіз безпілотних літальних апаратів мікроБПЛА. Отримані дані дозволили систематизувати існуючі на даний момент апарати і виділити відповідність їх конфігурації, що дозволить вибрати найбільш доцільну схему згідно з наявним досвідом розроблення.

Згідно з проаналізованими даними підібрано льотно-технічні параметри, тип двигуна і мультироторна схема, відповідні найбільш ефективним для мікроБПЛА за сферою застосування.

Результати цієї роботи можуть бути застосовані для подальшого проектування мікроБПЛА з малою тривалістю для заданих цілей.

\section{Список літератури}

1. Загальні види та характеристики безпілотних літальних апаратів: довід. посібник / Гребеніков А. Г.,. Мялиця А. К,. Парфенюк В. В та ін. - X .: Нац. аерокосм. ун-т "Харк. авіація. ун-т", 2008 - 377 с.

2. Сайт Airforce Technology [Електронний ресурс] - Режим доступу: https: //www.airforce-technology.com

3. Сайт Military Factory [Електронний ресурс] - Режим доступу: https: //www.militaryfactory.com

4. Світовий ринок безпілотників / Преображенський Н. - Військовий огляд [Електронний ресурс] - Режим доступу: https://topwar.ru/38994-mirovoy-rynokbespilotnikov.html

5. Гребеніков А. Г. Аналіз статистичних даних безпілотних літальних апаратів вертолітного типу / Гребеніков А. Г.,. Середа Т.Н,. Цепляєва Т.П, Шевченко Є.Ю., Юхно А.А. // Відкриті інформаційні та комп'ютерні технології: зб. наук. пр. Нац. аерокосм. Ун-та им. М.Є. Жуковського «XАІ». - Вип. 80 - X., 2018. - С. $5-22$.

6. Цепляєва Т.П. Аналіз сучасного стану розвитку висотних безпілотних літальних апаратів / Цепляєва Т.П.,. Мигунов А. Ю // Відкриті інформаційні та комп'ютерні технології: зб. наук. пр. Нац. аерокосм. Ун-та им. М.Є. Жуковського «XAl». - Вип. 83 - X., 2019. - С. 28 - 41.

\section{References}

1. Zagal'ni vy'dy' ta xaraktery 'sty`ky' bezpilotny'x lital'ny'x aparativ: dovid. posibny`k /. Grebenikov A. G.. Myaly cya A. K,. Parfenyuk V. V ta in. - X .: Nacz. aerokosm. un-t "Xark. aviaciya. un-t", 2008 - 377 s.Airforce Technology, available at: 
https: //www.airforce-technology.com/

2. Airforce Technology [Elektronny`j resurs] - Rezhy`m dostupu: https: //www.airforce-technology.com

3. Military Factory [Elektronny`j resurs] - Rezhy'm dostupu: https: //www.militaryfactory.com

4. Svitovy ‘j ry'nok bezpilotny 'kiv / Preobrazhens`ky`j N. - Vijs'kove oglyad [EIektronny`j resurs] - Rezhy'm dostupu: https://topwar.ru/38994-mirovoy-rynokbespilotnikov.html

5. Grebenikov A. G. Analiz staty 'sty 'chny $x$ dany`x bezpilotny $x$ lital'ny`x apara-tiv vertolitnogo ty'pu /. Grebenikov A. G,. Sereda T.N,. Ceplyayeva T.P..Shevchenko Ye.Yu,. Yuxno A.A // Vidkry'ti informacijni ta komp'yuterni texnologiyi: zb. nauk. pr. Nacz. aerokosm. Un-ta y`m. M.Ye. Zhukovs`kogo «XAl». Vy`p. $80-$ X., 2018. - S. 5- 22.

6. Ceplyayeva T.P. Analiz suchasnogo stanu rozvy 'tku vy'sotny'x bezpilotny 'x lital'ny'x aparativ / Ceplyayeva T.P., My'gunov A.Yu // Vidkry`ti informacijni ta komp'yuterni texnologiyi: zb. na-uk. pr. Nacz. aerokosm. Un-ta y’m. M.Ye. Zhukovs`kogo «XAl». - Vy’p. $83-$ X., 2019. - S. $28-41$.

Надійшла до редакції 25.10.2021, розглянута на редколегії 26.10.2021

\section{Analysis of the current state of development of micro unmanned aerial vehicles of multicopter type}

The development of unmanned aerial vehicles is of great interest to both the largest aircraft companies and design enthusiasts, and among the total volume of developments, the volume of multicopter unmanned aerial vehicles occupies one of the leading positions. In this regard, the analysis of existing developments and the definition of future research in this direction is relevant. Multi-helicopter drones have a wide range of functions in both military and civilian use.

The paper collects and analyzes statistical data of micro-unmanned aerial vehicles of the multicopter type to determine the achievements in the field of design of micro-unmanned aerial vehicles (UAVs). The current classification of UAVs is considered; as a result of the analysis of statistical data its expansion is offered. The take-off and mass characteristics of the micro UAV are described. The tables showing the existing UAVs are given. In addition, the flight characteristics, aerodynamic schemes and type of engine that are most rationally suited for micro-unmanned aerial vehicles according to their purpose and class are determined.

Based on the obtained data, a prototype model of a micro-UAV with improved characteristics was built. The model successfully completed all tasks. This indicates that the new UAV "Fear-1" is a successful project and it has the ability to remotely control by phone or any other equipment designed for this purpose. In addition, the designed device can additionally hang in the specified coordinates.

"Fear-1" confidently performs tasks in automatic mode, as well as independently decides to return to the starting point of takeoff, if: there is a loss of communication, the battery level has reached a certain level, the UAV has completed its task or used more miles -amperes than specified by the output parameters. The drone has the ability to fly in "Follow me" mode on the selected GPS transmitter. The quadcopter was tested in difficult weather conditions, when the wind force reached 8 points (about $22 \mathrm{~m} / \mathrm{s}$ ). Noise immunity tests were also performed in the industrial 
frequency range (from $2.4 \mathrm{GHz}$ to $5.8 \mathrm{GHz}$ ).

Key words: multicopter type micro UAV; flight technical characteristics; flight duration; engine; layout; drone.

\section{Відомості про авторів:}

Олександр Григорович Гребеніков - доктор технічних наук, профресор каф.103 «Проектування літаків і вертольотів» Національного аерокосмічного університету ім. М. Є. Жуковського "Харківський авіаційний інститут», Україна, e-mail: o.grebenikov@khai.edu. ORCID 0000-0002-1509-0665.

Калоша Олексій Сергійович - аспірант кафр.103 «Проектування літаків і вертольотів» Національного аерокосмічного університету ім. М. Є. Жуковського «Харківський авіаційний інститут», Україна, e-mail: o.kalosha@khai.edu

\section{About the Authors:}

Oleksandr Grebenikov - Doctor of Technical Sciences, Professor of Department 103 "Design of Airplanes and Helicopters" of the National Aerospace University "Kharkiv Aviation Institute", Ukraine, e-mail: o.grebenikov@khai.edu. ORCID 00000002-1509-0665.

Kalosha Oleksii- post-graduate student of department 103 "Design of airplanes and helicopters" of the National Aerospace University "Kharkiv Aviation Institute", Ukraine, e-mail: o.kalosha@khai.edu 